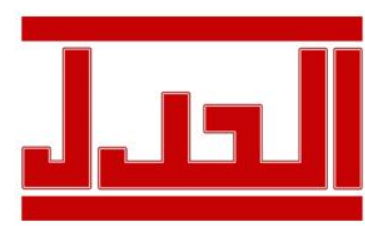

ISSN: $1979-4940$

E-ISSN : 2477-0124
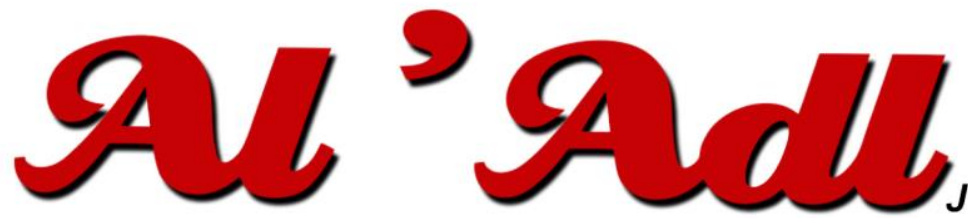

Jurnal Hukum

Editorial Office: Faculty of Law, Islamic University Of Kalimantan,

Jalan Adhyaksa No. 2 Kayutangi Banjarmasin, Kalimantan Selatan, Indonesia (70123)

Email: al_adl@uniska-bjm.ac.id

Web: http://ojs.uniska-bjm.ac.id

\title{
COMPARATIVE LAW AGAINST ONLINE PROSTITUTION ACCORDING TO INDONESIAN AND DUTCH LAW
}

\author{
Muhammad Akbar Ridha, Yati Nurhayati ${ }^{* 1}$ \\ Faculty of Law, Islamic University of Kalimantan MAB \\ J1. Brawijaya, Geblagan, Tamantirto, Kec. Kasihan, Bantul, Daerah Istimewa Yogyakarta \\ 55183 \\ Email: $\underline{\text { akbarridha42@gmail.com, nurhayati.law@gmail.com }}{ }^{* 1}$
}

*coressponding author

$\begin{array}{ll}\text { Submitted } & : \text { 09 Januari } 2022 \\ \text { Revised } & : \text { 20 Januari } 2022 \\ \text { Accepted } & : \text { 31 Januari } 2022 \\ \text { Published } & : \text { 2 Februari } 2022\end{array}$

\section{Abstract}

Prostitution is a complex problem. Hence it requires serious and comprehensive attention and handling from some aspects - moral, social, cultural, legal, or norms, etc. The legal norms from various different countries, including Indonesia, categorize prostitution as an illegal action, whereas others are silent with some exceptions. One of the countries legalizing prostitution is the Netherlands. When the Dutch government legalized prostitution in 2000, it was to protect women by giving them work permits. This research focuses on answering how the Comparison of Criminal Law Policies against Online Prostitution in Indonesia and the Netherlands is. The method used was normative legal research. The results showed that Indonesia prohibits prostitution even though the crime uses the relevance between the Criminal Code and certain laws as there is no specific legal policy regarding online prostitution in Indonesia. Meanwhile, the Dutch legal policy in responding to the online prostitution issue, legalizes prostitution with the terms and conditions of the Bibob law.

Keywords: Online Prostitution; Comparative Law; Indonesia; Netherlands

\section{INTRODUCTION}

The practice of online prostitution using the internet is still new, particularly in Indonesia. This happens along with the development of the internet in Indonesia. The ease of accessing the internet in a variety of online media increases the practice of online prostitution. Actually, prostitution is a vulnerable and complex problem. Therefore, this activity requires serious and comprehensive attention and handling of some aspects - moral, social, cultural, legal, or norms, etc. However, prostitution is hard to eliminate in any country. This refers to

\footnotetext{
${ }^{1}$ Correspondent Author
} 
the less religious understanding of society. ${ }^{2}$ Religion, one of the guidelines in life, is completely ignored by those who engage in this prostitution practice and this activity is prohibited by religion. Not only does prostitution become an individual symptom, but it also becomes a social symptom of abnormal sexuality and religious deviation. ${ }^{3}$ Factors causing online prostitution include low education, economic factors such as unemployment and necessities of life, sociological factors - persuasion from friends and deception, psychological factors - a broken family relationship, causing lack of attention from parents, biological factors such as abnormal sexual behaviors, juridical factors such as the absence of a legal prohibition on people who have sex before marriage, and supporting factors such as internet and a mobile phone that support someone to easily transact prostitution. ${ }^{4}$

Based on the rules applied in Indonesia, online prostitution is not a criminal offence stipulated in the Criminal Code (Criminal Code) that applies in Indonesia, as discussed in the Criminal Code is an act that facilitates the occurrence of online prostitution by providing a place or a mean to perform prostitution. The provisions are contained in Article 296, and 506 of the Criminal Code. ${ }^{5}$ Legal norms of different countries vary, some categorize it as a criminal offence, some are silent with some exceptions. One of the countries legalizing prostitution is the Netherlands. When the Dutch government legalized prostitution in 2000, it was to protect women by giving them work permits, but those who do the action now worry that the business is out of control. ${ }^{6}$ Under a law legalizing prostitution in the Netherlands, official brothels must have a permit that must be obtained from the local government - the city council. In theory, this could work, but local governments rarely grant permits to sex workers who choose to play by the rules. ${ }^{7}$ Many cities have policies whereby only existing brothels can renew their licenses, after going through a complicated procedure ('wet BIBOB')

\footnotetext{
${ }^{2}$ Ronny Soemitro, (2001). Study Hukum Dalam Masyarakat, Alumni, Bandung, hlm. 36.

${ }^{3}$ Terence H, Hull, Endang Sulistianingsih, Gavin W. J, Pelacuran di Indonesia (Pustaka Sinar Harapan, Jakarta 2003), hlm. 3.

4 Marta luvi manurung, (2014). jurnal peran kepolisian dalam menanggulangi prostitusi online, Universitas Atmajaya, Yogyakarta. hlm. 1.

5 Pasal 296 KUHP menjelaskan: "Barang siapa dengan sengaja menyebabkan atau memudahkan perbuatan cabul oleh orang lain dengan orang lain, dan menjadikannya sebagai pencarian atau kebiasaaan, diancam dengan pidana penjara paling lama satu tahun empat bulan atau dipidana denda paling banyak lima belas ribu rupiah". Pasal 506 KUHP menjelaskan: "Barangsiapa menarik keuntungan dari perbuatan cabul seorang wanita dan menjadikannya sebagai pencaharian, diancam dengan pidana kurungan paling lama satu tahun".

${ }^{6}$ Simons, Marlise (24 Februari 2008). "Amsterdam mencoba perbaikan kelas atas untuk kejahatan distrik lampu merah". The New York Times . (diakses 9 Juni 2010).

${ }^{7}$ In this weblog Felicia Anna explains how the city of Amsterdam threatened to close the brothel window in 2014 (which they later closed) Felicia Anna was a Romanian sex worker who opposed Amsterdam city policies and against prejudice in society. She tried to improve the position of sex workers by volunteering for Proud, a sex workers' union.
} 
where brothel owners must prove that their management always pays taxes properly and has never committed any crime. ${ }^{8}$

The lifting of the prostitution ban in 2000 through the Bibob Act has given the city council the authority to enforce any necessary rules in official brothels. The Bibob Law is designed to remove criminals from the legal business of prostitution and regulate the licensing of prostitution. Prostitution licenses will be revoked if brothel owners who have criminal records in their names, even if their only crime is related to operating a brothel before prostitution is legalized, does not pass bibob-law checks, some unauthorized brothel owners, act as criminal pimps. ${ }^{9}$

The problem of prostitution is a complicated problem, many things related to the problem that occurs, therefore this problem urgently needs special attention by the community. Prostitution, a business synonymous with the black world is a rival to one business that brings in money very quickly. Hence this business will not meet difficult times. The crime of prostitution is one of the crimes that has also grown since the existence of internet technology, in this case there is abuse of internet technology where the internet is used for marketing facilities for commercial sex workers. Prostitution activities are considered to bring great benefits to prostitutes and pimps, this eventually causes a settlement between prostitutes and pimps to dominate the market.

If the competition arises, then the prostitution business actors provide better services from their competitors including services for the ease and security of conducting prostitution transactions. By using internet security and ease in transacting prostitution is what can be obtained for prostitution business people, this eventually results in increasing violent crime of prostitution through the internet. To stem the crime of online prostitution, an active role is needed by law enforcement and the community itself. ${ }^{10}$

Regarding prostitution itself is certainly inseparable from the existence of Commercial Sex Workers (hereinafter referred to as prostitutes). Sex workers or prostitutes are workers tasked to serve sexual activities that aim to get rewards from users of their services. In the current Criminal Code only regulates the existence of prostitutes intermediaries or usually referred to as pimps as stipulated in the provisions of Article 296 of the Criminal Code and

${ }^{8}$ Undang-Undang Administrasi Publik (Probity Screening) (Bibob) Bibob adalah kependekan dari 'Wet bevordering integriteitsbeoordelingen door het openbaar bestuur', diambil dari situs web pemerintah Belanda 20 Juni 2021

${ }^{9}$ Walikota Amsterdam Menempatkan Pemerasan Di Fat Charlie Distrik Lampu Merah , Irish Times, 20 Januari 2007, (diakses 15 Juni 2021)

${ }^{10}$ Dianawati, A, (2006), Pendidikan Seks Untuk Remaja, Jakarta: Kawan Pustaka, hlm. 59. 
Article 506 of the Criminal Code, while for prostitutes there is no clear arrangement, so that the criminalization of prostitutes acts is currently only regulated in certain regional level laws and regulations only.

Existing regulations in Indonesia should be able to roll up the practice of prostitution through this virtual world. But unfortunately with the limitations that exist, the government has not been able to close cyber sites that clearly reek of prostitution practices. Indeed in this day and age technology such as one blade can be used for good things and if used for irresponsible people, it will cause harm to others. There is a legal protection that can be used in law enforcement efforts against prostitution through Law No. 19 of 2016 on Information and Electronic Transactions (or in short ITE law).

In addition, there are other legal rules outside the Law related to prostitution simultaneously in the Criminal Code (Criminal Code), Law No. 21 of 2007 on Human Trafficking, and Law No. 44 of 2008 on Pornography, regulations related to prostitution in the Act can basically also be applied in online prostitution crimes.

As long as the criminal code is still relevant to the crime of online prostitution, articles that have relevance can still be applied to ensnare online prostitution perpetrators. Indonesia is included as a country that actually legalizes prostitution activities but in reality prostitution activities still operate in many parts of Indonesia, even carried out in an organized and open and closed manner, even in a number of cities there are places that specifically localize places of prostitution commonly called localization.

Taking into account all of the factors above, the author is encouraged to raise and discuss it in a paper entitled "Comparative Law Against Online Prostitution According to Indonesian and Dutch Law".

\section{PROBLEM FORMULATION}

In order for the subject matter of the discussion in this article to be more directed and clear, then a formulation of the problem that focuses on answering how the Comparison of Criminal Law Policy Against Online Prostitution In Indonesia and the Netherlands is?

\section{RESEARCH METHOD}

This research is conducted through a normative juridical approach, which has the understanding that this research is based on the rule of law that applies and is closely related 
to criminal law. In this study, the author used normative studies, which are positive legal comparison approaches and applicable laws that are based on the rules contained in the laws and regulations, by containing descriptions that are studied based on a careful and in-depth literature review.

\section{DISCUSSIONS}

\section{Online Prostitution in the Perspective of the Indonesian Criminal Code}

The Criminal Code. Judging from the rule of law, prostitution activities can be regarded as an act that violates the rules of criminal law. In the Criminal Code Article 296 jo Article 506 regulated on Prostitution. Article 296 of the Criminal Code explains that: "Whoever intentionally causes or facilitates obscene acts with others, and makes them a livelihood and a habit, is threatened with imprisonment of a maximum of one year and four months or a maximum fine of fifteen thousand rupiah." Article 506 of the Criminal Code explains that: "Whoever withdraws the profits from a woman's obscene acts and makes them a livelihood, is threatened with imprisonment for a maximum of 1 year."

Against this provision in his book R. Soesilo entitled "The Criminal Code (Criminal Code) and Its Comments Are Complete Article By Article" explained that Article 296 ensnares people who hold brothels. This article makes it clear that it will be given imprisonment for a person whose work is intentionally committed obscene acts by others with third parties. While Article 506 explains that the pimp is a pervert broker, a man whose life seems to be financed by prostitutes living with him who is in assisting prostitution, seeking subscriptions from which he gets his share. ${ }^{11}$

\section{Online Prostitution and Trafficking in Indonesian Law}

Law No. 21 of 2007 concerning the Eradication of Human Trafficking. Law No. 21 of 2007 on Combating The Crime of Human Trafficking regulates the practice of prostitution with the article governing human trafficking. Human trafficking is any form of human trafficking, as well as exploitation of man himself such as prostitution (work or forced service), slavery or practices that resemble it, and also the trafficking or organ harvesting of

11 Novica A Pangaribuan, "Jerat Hukum Bagi Para Pihak Yang Terlibat Prostitusi", https://www.larasonline.com/ulasan/Jerat-Hukum-Bagi-Para-Pihak-Yang-Terlibat-Prostitusi, (diakses pada tanggal 23 Juni 2021). 
the human body. The Criminal Act of Human Trafficking (TPPO) which article can ensnare business people prostitution refers to Article 2 paragraph (1) and Paragraph (2). ${ }^{12}$

The law governing this is Law No. 21 of 2007 on Combating The Crime of Human Trafficking (hereinafter abbreviated as PTPPO Law). Other laws related to the PTPPO (Prevention of Human Trafficking Act), including Law No. 7 of 1984 on the Ratification of the Convention on the Elimination of All Forms of Discrimination against Women, Law No. 23 of 2002 on Child Protection. Most recently, Indonesia has also passed a protocol to prevent and crackdown on trafficking - Law No. 14 of 2009.

The PTPPO Law regulates basic protection for victims, in addition, this law also provides attention to the suffering of victims as a result of criminal acts of trafficking in the form of compensation (restitution) for victims and regulates medical and social rehabilitation, repatriation and reintegration that must be done by the state, especially for victims who experience physical, psychological, and social suffering due to the criminal act of trafficking. ${ }^{13}$

To further explore the form of protection against victims of trafficking crimes, there are several forms or models of protection that can be given to victims, as follows: ${ }^{14}$

1. Provision of Restitution

Every victim of the crime of trafficking or his/her heirs is entitled to restitution from the perpetrator. Based on article 48 paragraph (2) of the TPPO Law mentioned that restitution can be in the form of: ${ }^{15}$

a. Loss of wealth or income

b. suffering

c. costs for medical and/or psychological treatment; and/or

d. other losses suffered by victims as a result of trafficking

The PTPPO Law only explains that restitution is the right of the victim or his/her heirs, and the restitution is given and included in the court's ruling, it is not explained the size or indicator of the amount of restitution and the appropriate compensation given. In the case of victims with lower social status than the perpetrator, will prioritize

\footnotetext{
${ }^{12}$ Nasrullah \& Aden Rosadi, (2017), "Kritik Hukum Islam Atas Sanksi Pidana Pelaku Prostitusi Dalam Peraturan Daerah", Jurnal Al- 'Adalah, Vol. 14, Nomor 1, hlm. 60-61.

${ }^{13}$ Farhana, (2010), Aspek Hukum Perdagangan Orang di Indonesia, Cet 1, Jakarta: Sinar Grafika, hlm. 180.

${ }^{14}$ Ibid, hlm. 163.

15 Dikdik M. Arief Mansur Dan Elisatris Gultom, (2008), Urgensi Perlindungan Korban Kejahatan Antara Norma Dan Realita, (Jakarta: Pt Rajagrafindo, hlm. 166.
} 
compensation in material form, and conversely if the status of the victim is higher than the perpetrator then the recovery of the dignity and reputation will take precedence. ${ }^{16}$

From article 48 it can be seen that a form of loss called restitution is in the form of money. Thus, the purpose of compensation is the fulfillment of demands in the form of a reward for some money. Gelaway is quoted in Rena Yulia's book formulating the five goals of restitution obligations: ${ }^{17}$

a. Ease the suffering of victims

b. As an element that relieves the punishment that will be imposed

c. As a way to rehabilitate convicts

d. Simplify the judicial process

e. It can reduce the threat or reaction of the community in the form of acts of revenge.

2. Rehabilitation

Rehabilitation is the recovery from disorders of physical, psychological, and social conditions in order to carry out their role again reasonably both in the family and in society. Rehabilitation can be health rehabilitation and social rehabilitation. In the explanation of the PTPPO Law mentioned that medical rehabilitation / health is the recovery of the original condition both physical and psychological. Medical rehabilitation is provided to victims who suffer medically as a result of the criminal act of trafficking. Based on articles 51 and 52, the explanation of rehabilitation is basically as follows: ${ }^{18}$

a. Victims are entitled to health rehabilitation, social rehabilitation, repatriation, and social reintegration of the government if the person concerned experiences both physical and psychological suffering due to the criminal act of trafficking.

b. Rehabilitation is proposed by the victim or the victim's family, the victim's friend, police, volunteer escort or social worker, after the victim reports the case or other party who reported it.

c. Applications are submitted to the government through ministers or agencies that deal with health and social issues in the area.

d. The minister or agency handling rehabilitation, must provide health rehabilitation, social rehabilitation, repatriation and social reintegration no later than 7 days from the time of application.

${ }^{16}$ Rena Yulia, (2013), Viktimologi Perlindungan Hukum terhadap Korban Kejahatan, Cet 2, Yogyakarta: Graha Ilmu, hlm. 60.

${ }^{17}$ Ibid., hlm. 179.

${ }^{18}$ Bambang Waluyo, Op.Cit., hlm. 123. 
e. For the implementation of health rehabilitation services, social rehabilitation, repatriation, and social reintegration of the government and local governments must establish social protection houses or trauma centers with the aim of providing awareness to them to a good path in accordance with applicable norms. ${ }^{19}$

3. Repatriation and Social Reintegration

Social reintegration means the reunification of victims of trafficking crimes to the family or the replacement of families that can provide protection and fulfillment of needs for victims. Moreover, when associated with the unavailability of a place where the victim can stay longer there. Victims who are abroad are entitled to be protected and repatriated to Indonesia at the country's expense. As stated in article 54 of the PTPPO Act:

Article 54 paragraph (1):

In the event that the victim is abroad requires legal protection due to the criminal act of trafficking, the government of the Republic of Indonesia through its representatives abroad is obliged to protect the personal and interests of the victim, and strive to repatriate the victim to Indonesia at the country's expense.

This law regulates the protection of witnesses and victims as an important aspect in law enforcement that aims to provide basic protection to victims and witnesses. In the PTPPO Law, the protection of victims and witnesses is regulated from article 43 to article 55. Article 51 to article 54 of UUPTPPO which successively regulates the confidentiality of the victim's identity, the right to restitution or compensation, both related to property rights, costs during legal proceedings, both domestically and abroad, and the restitution must be included at once in the court's decision. ${ }^{20}$

Furthermore, through articles 60 to article 63 accommodated the participation of the community to help the prevention and handling of victims of trafficking crimes. ${ }^{21}$ This provision is implemented under Law No. 13 of 2006 on The Protection of Witnesses and Victims. Article 3 regulates the trafficking of people whose victims are not only Indonesian Citizens (WNI) but also Foreigners (WNA), but the location of trafficking is

${ }^{19}$ Abdul Aziz Dahlan, (1996), Ensiklopedi Hukum Islam, Cet Ke-1, Jilid 4 , Jakarta: Ichtiar Baru Van Hoeve, hlm. 1421.

${ }^{20}$ Alfan Alfian, (2015), “Fiat Justisia Jurnal Ilmu Hukum” Upaya Perlindungan Hukum Terhadap Korban Tindak Pidana Perdagangan Orang,Volume 9, Nomor 3, (diakses Pada Tanggal 3 Agustus 2021).

${ }^{21}$ Bambang Waluyo, (2014), Viktimologi Perlindungan Korban Dan Saksi, Cetakan 3, Jakarta: Sinar Grafika, hlm. 120 . 
in the territory of the Republic of Indonesia. Although not Indonesians, this law still protects the victims. $^{22}$

Prostitution itself is a form of sexual exploitation, which is meant by sexual exploitation is any form of utilization of sexual organs or other organs of the victim for profit, including but not limited to all prostitution and fornication activities. ${ }^{23}$ In the PTPPO Law that can be used to ensnare prostitution perpetrators contained in articles 2, 3, and 4 .

\section{Online Prostitution in the Perspective of Pornography Law}

Law No. 44 of 2008 on Pornography. Prostitution arrangements are also regulated in Law No. 44 of 2008 on Pornography which defines pornography broadly as encompassing images, photos, conversations, body language, or any message in various forms of communication and public performance containing obscenity that violates moral norms. Educational materials for HIV prevention and health promotion are not intended to fall into the definition of pornography under this law. ${ }^{24}$

The crime of pornography with online prostitution has a close relationship. This is because in offering sexual services to customers, prostitutes will certainly share images, videos, writings or others that contain pornographic elements. Once they see or listen to images, videos, writings or others that contain pornographic elements sent by prostitutes can make their sexual desires uncontrollable. Do not rule out the possibility that they will have sexual relations with prostitutes as fulfillment of their sexual desires. A person who uses this online prostitution service to fulfill his sexual desires is not only a teenager who does not have a legal partner, even someone who is married or already has a legal partner also does not rule out the possibility of being a customer or user of online prostitution services. ${ }^{25}$

The Pornography Act states that everyone is prohibited from producing, creating, multiplying, doubling, disseminating, broadcasting, importing, exporting, offering, trading, renting, or providing pornography that explicitly contains pornography:

1. Adultery, including a type of adultery which

2. Perversion;

22 Henny Nuraeny, (2013), Tindak Pidana Perdagangan Orang "Kebijakan Hukum Pidana Dan Penerapannya, Cetakan Ke-2, Jakarta: Sinar Grafika, hlm. 132.

${ }^{23}$ Pasal 1 Ayat (8) Undang-Undang Nomor 21 Tahun 2007 tentang Pemberantasan Tindak Pidana Perdagangan Orang.

${ }^{24}$ Nasrullah \& Aden Rosadi, Op.Cit., hlm. 60. hlm. 187.

${ }^{25}$ Neng Djubaedah, (2003), Pornografi dan Pornoaksi Ditinjau Dari Hukum Islam, Jakarta: Kencana, 
3. Sexual Assault;

4. Masturbation;

5. Nudity or an impressive display of

6. Nudity;

7. Genitals; or

8. Child Pornography. ${ }^{26}$

In the event that men and women give mutual consent to the recording of their sexual videos and are only used for their own benefit as referred to in the exceptions described in The Explanation of Article 4 paragraph (1) of the Pornography Act, then the act of manufacture and storage is not included in the scope of "making" as referred to in Article 4 paragraph (1) of the Pornography Act. Whereas if the shooting or recording is unknown or without the consent of the woman or man of his partner, then the making of the video violates Article 4 paragraph (1) of the Pornography Act. Consent is a very vital part in determining whether or not there is a violation. In the distribution of pornography, when the creation of a video or photo is approved by the parties, the dissemination by one party can make the other party entangled in criminal provisions, as long as the party does not expressly give a prohibition for its dissemination. For example, if men and women agree or give mutual consent to the creation of pornographic photos or recordings, then men distribute pornography but women have not previously made a statement expressly to prohibit men or disclose pornography then women can be criminally charged with the spread of pornography. Conversely, if a woman has previously made a firm statement that she agrees to make pornography but does not allow men to disclose or disseminate pornography then women have a stronger position not to be blamed for participating in the spread of pornography. Likewise, if the woman is not aware of the creation of pornographic photos or videos or does not give consent to the creation of pornography then in this case the woman can be called a victim of pornographic content distribution. ${ }^{27}$

In the pornography law everyone is prohibited from providing pornographic services that:

1. Explicitly present nudity or an impressive display of nudity;

2. Explicitly presenting the genitals;

3. Exploiting or exhibiting sexual activity; or

${ }^{26}$ Pasal 4 Ayat (1) Undang-Undang Nomor 44 Tahun 2008 tentang Pornografi.

${ }^{27}$ Josua Sitompul, "Sanksi bagi Pembuat dan Penyebar Konten Pornografi", https://m.hukumonline.com/klinik/detail/ulasan/lt540b73ac32706/sanksi-bagi-pembuat-dan-penyebar-kontenpornografi/ (diakses 23 Juni 2021). 
4. Offer or advertise, either directly or indirectly sexual services. ${ }^{28}$

Online prostitution often advertises sexual services using images or videos that contain pornographic elements. The activity of offering or advertising sexual services is carried out directly or indirectly. In Article 30 of Law No. 44 of 2008 on Pornography it explains that: "everyone who provides pornographic services as referred to in Article 4 paragraph (2) is punishable by imprisonment of at least 6 (six) months and a maximum of 6 (six) years and or a fine of at least 250,000,000.00 IDR (two hundred and fifty million rupiah) and at most 3,000,000,000, 00 IDR (three billion rupiah)."

\section{Ban on Online Prostitution in Indonesia's ITE Law}

Indonesian Law No.11 of 2008 on Information and Electronic Transactions (UU ITE) does not mention the word prostitution in all articles. Except in article 27 paragraph (1) which contains about prohibited acts, mentioning the word decency that concerns matters that smell of pornography. Article 27(1) of the ITE Act explains that: "everyone who is intentional and without the right to distribute and/or separate and/or make accessible Electronic Information and/or Electronic files that have a charge that violates decency." Decency in Article 27 paragraph (1) means good customs or habits in relations between members of society, especially those related to sexuality (adultery). The act of "distributing" in the ITE Law is defined as the activity of sending and/ or disseminating Electronic Information and or Electronic files to many people or various parties through electronic systems. While transmitting itself is defined as the activity of sending Electronic Information and or Electronic files addressed to one other party through an Electronic System. Any person who violates Article 27 of the ITE Law will be subject to criminal threats as contained in Article 45 paragraph (1) of Law No. 19/2016 (as a change to Law No. 11/2008) on Information and Electronic Transactions (UU ITE) with the threat of imprisonment of a maximum of 6 years and/or a maximum fine of 1 billion IDR.

The perpetrators, in this case prostitutes can be subject to the ITE Law because in doing their actions indirectly also do other actions that send or disseminate information or electronic files (either in the form of images or video impressions or recordings) that are charged with decency through computers, computer networks, and or other electronic media. In this case according to the authorities, the perpetrator sends content (information, images,

\footnotetext{
${ }^{28}$ Pasal 4 Ayat (2) Undang-Undang Nomor 44 Tahun 2008 tentang Pornografi.
} 
videos, etc.) that is charged with decency to pimps and/or prospective users of sexual services through messages with social media platforms that can only be done online with electronic media. Thus the perpetrator or prostitute is not threatened criminally because of the act of prostitution she/he did (his/her prostitution practice) but because he/she has sent or disseminated information or electronic documents that are charged with decency through electronic media. ${ }^{29}$

\section{Legalization of Dutch Prostitution Through Wet BIBOB}

Despite legal changes to make prostitution legal at the national level, many city councils act in the opposite direction, making prostitution illegal. Under a law legalizing prostitution in the Netherlands, brothels. ${ }^{30}$ Official must have a permit that must be obtained from the local government, namely the city council. ${ }^{31}$ Many cities have policies under which brothels can have their licenses after going through a complicated procedure ('wet BIBOB') where brothel owners must prove that management always pays taxes and never commits any crime. $^{32}$ The authorities have a convenient duty to realize their goals. Under the administration of a law passed in 2003 (known as BIBOB), local officials are empowered to withhold or revoke licenses or government subsidies for "high-risk" businesses (i.e., bars, hotels, restaurants, marijuana cafes, headshops, casinos, brothels, or escort agents) if the owner is suspected of committing a criminal offense or unable to prove that or its income and financing is legitimate. The burden of proof falls on the owner or prospective buyer, and authorities can base their decisions on the confidentiality of the information. Since BIBOB is an administrative mechanism, not a criminal law, the authorities do not have to prove criminal activity and can refuse or revoke a business license based solely on suspicion of criminality, lack of transparency in financial matters, or belief that the business may be involved in future crimes. In 2007, for example, four people lost their licenses for 100 windows. The

29 Nathalina Naibaho, "Prostitusi Online dan Hukum Pidana Oleh: Nathalina Naibaho*)", https://www.hukumonline.com/berita/baca/lt5c5abece7e335/prostitusi-online-dan-hukum pidanaoleh-nathalina-naibaho?page =2, (diakses 23Juni 2021).

30 Rumah bordir adalah tempat yang digunakan untuk pelacuran atau prostitusi. https://id.wikipedia.org/wiki/Bordil

${ }^{31}$ In this weblog Felicia Anna explains how the city of Amsterdam threatened to close the brothel window in 2014 (which they later closed) Felicia Anna was a Romanian sex worker who opposed Amsterdam city policies and against prejudice in society. She tried to improve the position of sex workers by volunteering for Proud, a sex workers' union.

${ }^{32}$ Undang-Undang Administrasi Publik (Probity Screening) (Bibob) Bibob adalah singkatan dari 'Wet bevordering integriteitsbeoordelingen door het openbaar bestuur', diambil dari situs web pemerintah Belanda 20 Juni 2020 
justification for this action, according to officials, is that "there is a risk that individuals are using their licenses to commit crimes." In addition to business owners suspected or charged with $\mathrm{BIBOB}$ violations, other owners have been pressured to sell their buildings or persuaded to do so with favorable payments.

The lifting of the prostitution ban in 2000 through the Bibob Act gave the city council the authority to enforce any necessary rules in official brothels. The Bibob Law is designed to remove criminals from the legal business of prostitution and regulate the licensing of prostitution. Prostitution licenses will be revoked if brothel owners who have criminal records in their names, even if their only crime is related to operating a brothel before prostitution is legalized, does not pass bibob-law checks, some unauthorized brothel owners, acting as criminal pimps. The biggest resentment of brothel owners is the removal of their permits, so they have little choice but to abide by the rules. ${ }^{33}$ Many sex workers lose their safe workplaces, because they are foreign nationals from outside the EU, forced to work underground, unable to obtain work permits. ${ }^{34}$

In the Netherlands, prostitution is legal in sex clubs and red light districts. While many local governments ban street-level prostitution, others have designated zones for such prostitution, with parking lots for sex workers and clients to meet, and waiting rooms for sex workers to socialize, get health and safety information, and new needles and condoms. Article $273 \mathrm{f}$ (formerly 250a).

The Dutch Penal Code is designed to distinguish between voluntary and involuntary prostitution. Those who choose sex work as a job should be given the same rights as other workers, while those who coerce or exploit prostitutes should be severely punished (imprisonment of up to 18 years in bad circumstances). According to the Department of Justice, it is expected that the new law will: protect prostitutes from commercial exploitation, combat prostitution and forced illicit trafficking, combat juvenile sexual abuse; promote the position of individuals working as prostitutes; eliminate criminal involvement in the prostitution industry, and limit the number of non-EU residents working as prostitutes in the Netherlands. While the Criminal Code punishes those who coerce or persuade someone into prostitution, municipalities are primarily responsible for regulating sex work within their boundaries. Penalties range from warnings, to fines, to temporary or permanent revocation of

\footnotetext{
${ }^{33}$ Tanggung jawab pengusaha dalam prostitusi lokal yang dilegalkan di Belanda Penelitian oleh Eelco van Wijk dan Peter Mascini, Vrije Universiteit Amsterdam, Diterbitkan pada 2019, diambil 15 Juli 2020

${ }_{34}$ Penelitian Kebijakan Prostitusi di Belanda oleh Marjan Wijers, diterbitkan pada 2008, (diakses 15 Juli 2020).
} 
licenses. In cases involving accidental prostitution, the owner and/or operator may be charged under the Criminal Code.

\section{Comparison between Indonesian law and Dutch law}

In a system of violations or prohibisionists where prostitution is prohibited, the state can give punishment in accordance with the applicable laws of the country. Where prostitution is allowed and regulated, with state policies and regulations. ${ }^{35}$ There are four types of prohibisionist systems, as follows:

1. In socialist or communist countries, this prohibition was imposed with the aim of eliminating prostitution, because it is not in accordance with the ideals and values of the state. Prostitution itself is rejected in the capitalist market and considered exploiting. In communist countries, although illegal, prostitution is a victim. But in reality protitusi is treated as in a capitalist country.

2. Capitalist prohibition, prostitution is prohibition, immorality and illicit relations. Prostitution, pimping and its customers/clients can be criminalized. ${ }^{36}$

3. New regulations on prostitution state that being prostitution is a woman's right. Starting from the right to self-determination. This right is enjoyed by both adult men and women who have the freedom to determine acts as prostitution and may benefit from it. This is the forerunner of the neo-abolitionism.

4. Abolitionists, in the 19th century, the abolitionist movement led by Josephin Buttler, against state regulations on prostitution. Allows prostitution, but imposes sanctions on pimps, prostitution houses, third parties who commit prostitution, trafficking people for sexual exploitation, and hotel prostitution. Abolitionist forms form the basis for conventions for the oppression, trafficking of people and the exploitation of sex by third parties, which have been committed by the United Nations, prostitution violates human rights and is harmful to the well-being of individuals, families and communities. In other words, prostitution is allowed as long as it does not endanger safety and public order. But it remains a social problem for the country.

35 Baary, Kathleen. (1995), The prostitution of sexusuality. NYU Press. dapat diakses di: https://www.jstor.org/stable/j.ctt9qg779.11?seq=1\#metadata_info_tab_contents.

${ }^{36}$ Ibid., hlm. 224. 
So to make it easier to know the comparison of criminal law policies against online prostitution in Indonesia and the Netherlands following the explanation through the table below:

\begin{tabular}{|c|c|c|c|c|c|}
\hline \multirow[t]{2}{*}{ No } & \multirow[b]{2}{*}{$\begin{array}{c}\text { Rule of } \\
\text { Law }\end{array}$} & \multicolumn{2}{|c|}{ Indonesia } & \multicolumn{2}{|c|}{ The Netherlands } \\
\hline & & $\begin{array}{c}\text { Indonesian } \\
\text { law }\end{array}$ & $\begin{array}{c}\text { Article } \\
\text { explanation }\end{array}$ & $\begin{array}{c}\text { Wet } \\
\text { Bibob } \\
\text { Law }\end{array}$ & Article explanation \\
\hline 1 & $\begin{array}{l}\text { Brothel- } \\
\text { related } \\
\text { arrangeme } \\
\text { nts }\end{array}$ & $\begin{array}{c}\text { Criminal Code } \\
284,296 \text {, and } \\
506\end{array}$ & $\begin{array}{l}\text { - Article 284: } \\
\text { Adultery } \\
\text { - Article 296: } \\
\text { Facilitating } \\
\text { prostitution } \\
\text { - Article 506: } \\
\text { Taking } \\
\text { advantage of } \\
\text { prostitution }\end{array}$ & $\begin{array}{c}\text { Article } \\
149\end{array}$ & $\begin{array}{l}\text { Acquired to have a } \\
\text { brothel with a } \\
\text { maximum municipal } \\
\text { limit }\end{array}$ \\
\hline 2 & $\begin{array}{c}\text { Terms on } \\
\text { Service } \\
\text { Users }\end{array}$ & $\begin{array}{c}\text { Article } 284 \\
\text { (with certain } \\
\text { qualifications) }\end{array}$ & $\begin{array}{l}\text { - If there is a } \\
\text { complaint } \\
\text { against the user } \\
\text { of the user's } \\
\text { spousal/wife } \\
\text { prostitution } \\
\text { service }\end{array}$ & - & \\
\hline 3 & $\begin{array}{l}\text { Provisions } \\
\text { on } \\
\text { Prostitutes }\end{array}$ & $\begin{array}{c}\text { Article } 284 \\
\text { (with certain } \\
\text { qualifications) }\end{array}$ & $\begin{array}{l}\text { - Adultery } \\
\text { outside of } \\
\text { marriage }\end{array}$ & $\begin{array}{c}\text { Article } \\
151 \mathrm{a}\end{array}$ & $\begin{array}{c}\text { Licensed psk } \\
\text { registered social } \\
\text { service }\end{array}$ \\
\hline 4 & $\begin{array}{c}\text { Provisions } \\
\text { against } \\
\text { Pimps or } \\
\text { other } \\
\text { parties }\end{array}$ & $\begin{array}{l}\text { - Pimps in } \\
\text { Article } 296 \\
\text { - Brothel } \\
\text { Owner, } \\
\text { Business }\end{array}$ & $\begin{array}{l}\text { - Article 296: } \\
\text { Facilitating } \\
\text { prostitution } \\
\text { - Article 506: } \\
\text { Taking }\end{array}$ & $\begin{array}{c}\text { Article } \\
149\end{array}$ & $\begin{array}{l}\text { Acquired to have a } \\
\text { brothel with a } \\
\text { maximum municipal } \\
\text { limit }\end{array}$ \\
\hline
\end{tabular}




\begin{tabular}{|c|c|c|c|c|c|}
\hline & & $\begin{array}{l}\text { Owner or } \\
\text { Building } \\
\text { Owner in } \\
\text { Article } 506\end{array}$ & $\begin{array}{l}\text { advantage of } \\
\text { prostitution }\end{array}$ & & \\
\hline 5 & $\begin{array}{l}\text { Provisions } \\
\text { for the } \\
\text { spreader of } \\
\text { immoral } \\
\text { content }\end{array}$ & $\begin{array}{c}\text { Daw No. } 44 \text { of } \\
\text { 2008 on } \\
\text { Article } 1 \\
\text { number } 1 \text { of } \\
\text { Pornography }\end{array}$ & $\begin{array}{l}\text { to prohibit } \\
\text { distributing, } \\
\text { transmitting, } \\
\text { and/or making } \\
\text { accessible } \\
\text { electronic } \\
\text { information or } \\
\text { documents that } \\
\text { violate decency } \\
\text { drawing, sketch, } \\
\text { illustration, } \\
\text { photograph, } \\
\text { writing, sound, } \\
\text { sound, moving } \\
\text { image, } \\
\text { animation, } \\
\text { cartoon, } \\
\text { conversation, } \\
\text { gesture, or other } \\
\text { form of message } \\
\text { through various } \\
\text { forms of } \\
\text { communication } \\
\text { media and/or } \\
\text { public } \\
\text { performances, } \\
\text { which contain } \\
\text { obscenity or }\end{array}$ & $\begin{array}{c}\text { Article } \\
273 f\end{array}$ & $\begin{array}{l}\text { Any form of } \\
\text { exploitation or } \\
\text { trafficking of persons } \\
\text { for prostitution is } \\
\text { prohibited }\end{array}$ \\
\hline
\end{tabular}









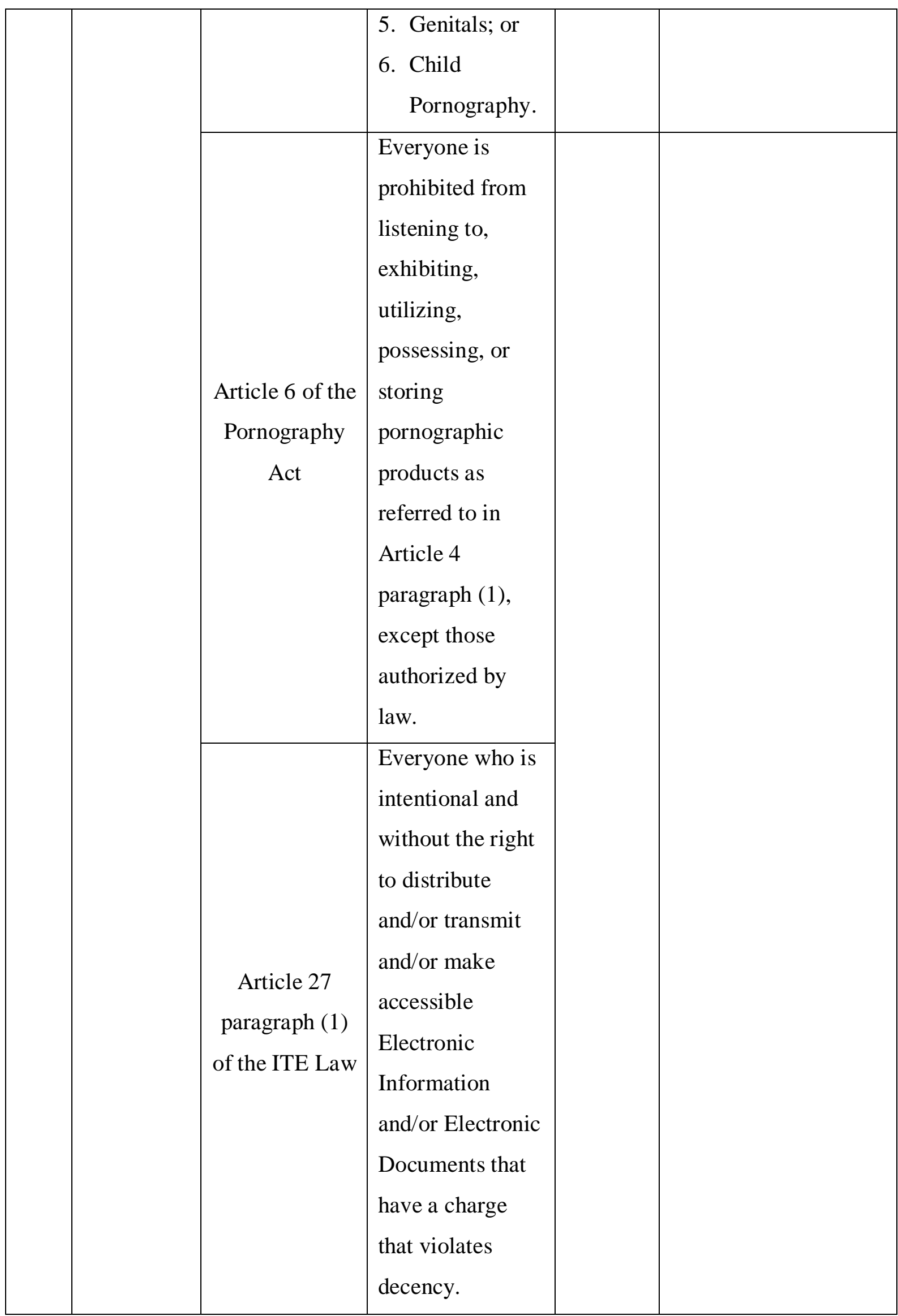




\begin{tabular}{|c|c|c|c|c|c|}
\hline 6 & $\begin{array}{c}\text { Child } \\
\text { Prostitutio } \\
\text { n } \\
\text { Provisions }\end{array}$ & $\begin{array}{c}\text { Law No. } 35 \text { of } \\
2014 \text { on } \\
\text { Amendments } \\
\text { to Law No. } 21 \\
\text { of } 2002 \text { on } \\
\text { Child } \\
\text { Protection }\end{array}$ & $\begin{array}{l}\text { - Obscene Acts } \\
\text { against } \\
\text { Children in } \\
\text { Article 76E } \\
\text { - Child } \\
\text { trafficking } \\
\text { under Article } \\
\text { 76F } \\
\text { Article 76I } \\
\text { against child } \\
\text { prostitutes } \\
\text { users }\end{array}$ & $\begin{array}{c}\text { Article } \\
248 b\end{array}$ & $\begin{array}{l}\text { Protection for children } \\
\text { under the age of } 16 \text { in } \\
\text { the case of prostitution } \\
\text { is not allowed }\end{array}$ \\
\hline 7 & $\begin{array}{c}\text { Prostitutio } \\
\qquad \mathrm{n} \\
\text { provisions } \\
\text { as a } \\
\text { people's } \\
\text { trade }\end{array}$ & $\begin{array}{c}\text { Law No. } 21 \text { of } \\
2007 \text { on } \\
\text { Combating } \\
\text { The Crime of } \\
\text { Human } \\
\text { Trafficking }\end{array}$ & $\begin{array}{l}\text { - Exploitation of } \\
\text { Indonesian } \\
\text { citizens in the } \\
\text { territory of } \\
\text { Indonesia in } \\
\text { Article } 2 \\
\text { - Entering } \\
\text { foreigners to } \\
\text { Indonesia or } \\
\text { abroad } \\
\text { Article } 3 \\
\text { - Delivery of } \\
\text { Indonesian } \\
\text { citizens to the } \\
\text { territory } \\
\text { Indonesia of } \\
\text { abroad } \\
\begin{array}{l}\text { Article } 4 \\
\text { - Removal of } \\
\text { Children }\end{array}\end{array}$ & $\begin{array}{c}\text { Article } \\
273 \mathrm{f}\end{array}$ & $\begin{array}{c}\text { Any form of } \\
\text { exploitation or } \\
\text { human trafficking for } \\
\text { prostitution is } \\
\text { prohibited }\end{array}$ \\
\hline
\end{tabular}




\begin{tabular}{|l|l|l|l|}
\hline & Exploitation in \\
Article 5 & \\
Child & & \\
Trafficking in & & \\
& Article 6 & & \\
\hline
\end{tabular}

\section{CONCLUSIONS}

Based on the results of research on the Comparison of Law against Online Prostitution according to Indonesian and Dutch Law, it can be concluded that the law in Indonesia against online prostitution clearly prohibits prostitution even though the criminal act uses relevance between the Criminal Code and certain laws due to the absence of special legal policies related to online prostitution in Indonesia. While the Dutch legal policy in response to the problem of online prostitution allows prostitution but in accordance with the terms and conditions of the Wet Bibob law. The general ban on brothels was lifted on October 1, 2000 in the Netherlands. At the heart of the law change is that forms of prostitution in which adult prostitutes voluntarily engage under certain conditions so that they are no longer prohibited. Legislators tried to find a balance between freedom of prostitution and protection against the harm caused by this phenomenon by making a new section of Law 250a of the Dutch Penal Code punish all forms of exploitation in the prostitution sector, and reviewing the decadence law, a number of relevance parts of the law were changed, especially with a view to more effective protection of minors. Section 250a was tightened, extended and re-numbered and this resulted in

Section

273f. 


\section{DAFTAR PUSTAKA}

\section{Books}

Abdul Aziz Dahlan, 1996. Ensiklopedi Hukum Islam, Cet Ke-1, Jilid 4 , Jakarta: Ichtiar Baru Van Hoeve.

Bambang Waluyo, 2014. Viktimologi Perlindungan Korban Dan Saksi, Cet 3, Jakarta: Sinar Grafika.

Dianawati, A, 2006. Pendidikan Seks Untuk Remaja, Kawan Pustaka, Jakarata.

Dikdik M. Arief Mansur Dan Elisatris Gultom, 2008. Urgensi Perlindungan Korban Kejahatan Antara Norma Dan Realita, Jakarta: PT Raja Grafindo.

Eelco van Wijk dan Peter Mascini, 2019. Tanggung jawab pengusaha dalam prostitusi lokal yang dilegalkan di Belanda, Vrije Universiteit Amsterdam.

Farhana, 2010. Aspek Hukum Perdagangan Orang di Indonesia, Cet 1, Jakarta: Sinar Grafika.

Henny Nuraeny, 2013. Tindak Pidana Perdagangan Orang "Kebijakan Hukum Pidana Dan Penerapannya, Cet Ke-2, Jakarta: Sinar Grafika.

Neng Djubaedah, 2003. Pornografi dan Pornoaksi Ditinjau Dari Hukum Islam, Jakarta: Kencana.

Rena Yulia, 2013. Viktimologi Perlindungan Hukum terhadap Korban Kejahatan, Cet 2, Yogyakarta: Graha Ilmu.

Ronny Soemitro, 2001. Study Hukum Dalam Masyarakat, Alumni, Bandung.

Terence H, Hull, Endang Sulistianingsih, Gavin W. J, 2003. Pelacuran di Indonesia. Pustaka Sinar Harapan, Jakarta.

\section{Legislation}

Kitab Undang Undang Hukum Pidana

Undang Undang Nomor 23 Tahun 2002 tentang Perlindungan Anak

Undang Undang Nomor 21 Tahun 2007 tentang Perdagangan Orang

Undang Undang Nomor 44 Tahun 2008 tentang Pornografi

Undang-Undang Nomor 19 Tahun 2016 tentang Perubahan Undang-Undang Nomor 11 Tahun 2008 tentang Informasi dan Transaksi Elektronik (UU ITE)

Wetsvoorstel. Wet regulering prostitutie en bestrijding misstanden seksbranche. KST. 221, nr. 2.; Memoire van Toelichting. KST. 32 211, nr. 3.; Naderrapport. KST. 32 211, nr. 4; Gewijzigd Voorstel van Wet (29 maart 2011). KST. 32211 A.

\section{Journals}


Alfan Alfian, (2015). "Upaya Perlindungan Hukum Terhadap Korban Tindak Pidana Perdagangan Orang“, Fiat Justisia Jurnal Ilmu Hukum, Volume 9, Nomor 3.

Marta Luvi Manurung, (2014), Jurnal Peran Kepolisian Dalam Menanggulangi Prostitusi Online, Universitas Atmajaya, Yogyakarta.

Nasrullah \& Aden Rosadi, (2017), "Kritik Hukum Islam Atas Sanksi Pidana Pelaku Prostitusi Dalam Peraturan Daerah", Jurnal Al- 'Adalah, Vol. 14, Nomor 1.

Simons, Marlise, (2008). "Amsterdam mencoba perbaikan kelas atas untuk kejahatan distrik lampu merah", The New York Times.

\section{Websites}

Baary, Kathleen. (1995), The prostitution of sexusuality. NYU Press. dapat diakses di: https://www.jstor.org/stable/j.ctt9ag779.11? seq=1\#metadata_info_tab_contents.

Nathalina Naibaho, "Prostitusi Online dan Hukum Pidana Oleh: Nathalina Naibaho*)", https://www.hukumonline.com/berita/baca/lt5c5abece7e335/prostitusi-onlinedan-hukumpidanaoleh--nathalina-naibaho?page $=2$.

Novica A Pangaribuan, "Jerat Hukum Bagi Para Pihak Yang Terlibat Prostitusi", https://www.larasonline.com/ulasan/Jerat-Hukum-Bagi-Para-Pihak-YangTerlibat-Prostitusi.

Josua Sitompul, "Sanksi bagi Pembuat dan Penyebar Konten Pornografi", https://m.hukumonline.com/klinik/detail/ulasan/lt540b73ac32706/sanksi-bagipembuat danpenyebar-konten-pornografil

Rumah bordir adalah tempat yang digunakan untuk pelacuran atau prostitusi. https://id.wikipedia.org/wiki/Bordil 